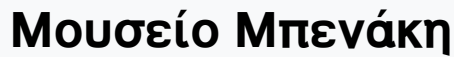

Tóp. 1, Ap. 11-12 (2012)

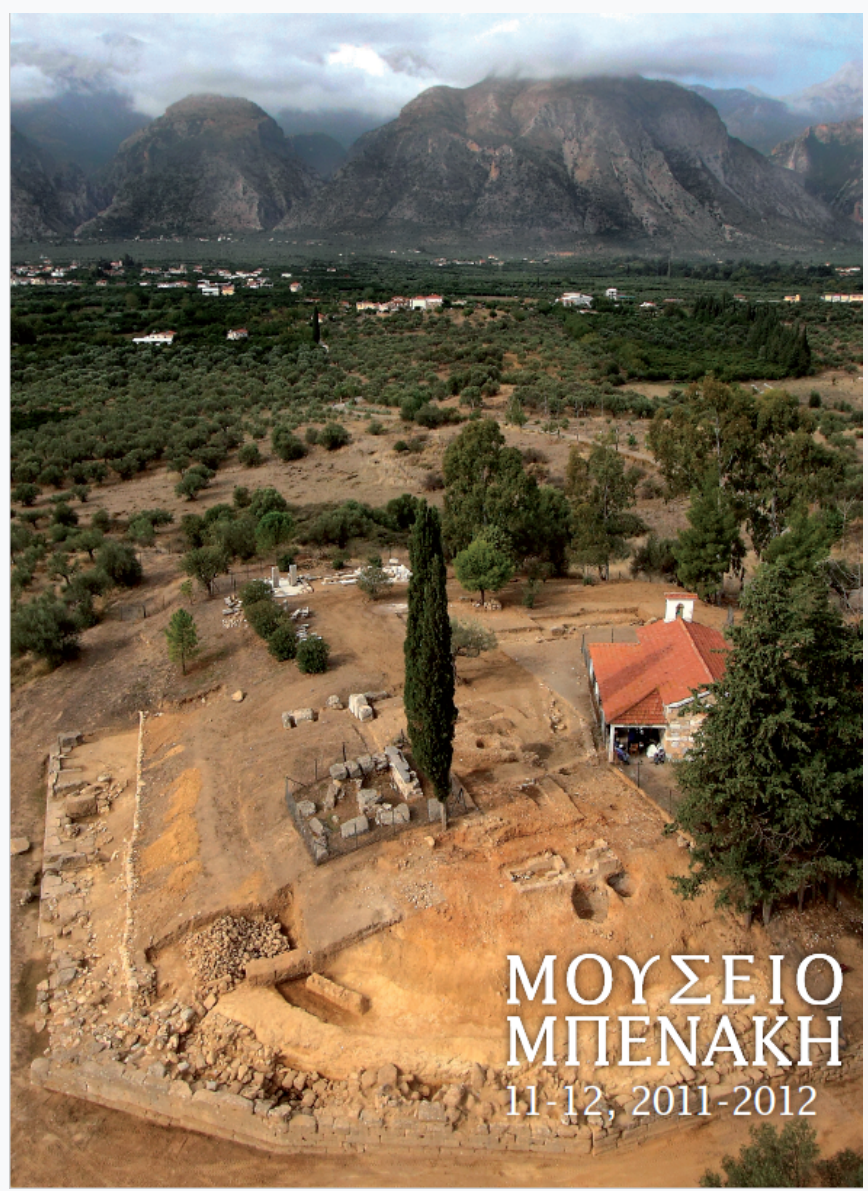

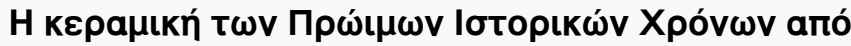

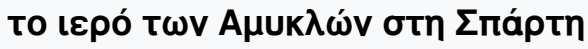

Vicky Vlachou

doi: $\underline{10.12681 / \text { benaki.17774 }}$

Copyright $($ 2018, Vicky Vlachou

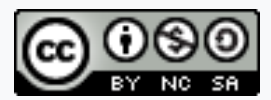

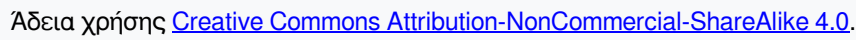

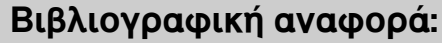

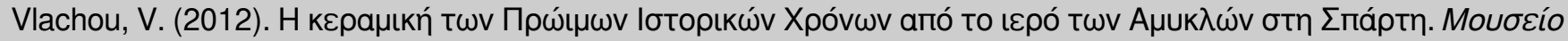

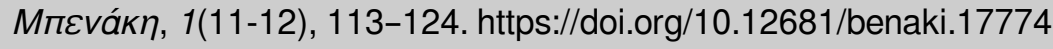




\section{The Spartan Amyklaion: the Early Iron Age Pottery from the Sanctuary}

HE SANCTUARY OF Apollonos en Amyklaioi

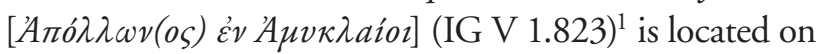
the low hill of Agia Kyriaki roughly $600 \mathrm{~m}$ to the east of the modern village of Amykles (Sklavochori or Slavochori). ${ }^{2}$ The sanctuary was famous for the imposing throne of Apollo that dominated the hilltop ${ }^{3}$ and the celebrated Hyakinthia, a three-day festival described at length in Deipnosophistai by Athenaios (4. 138f-140a). Despite the importance of the sanctuary in the history of Sparta and Laconia, its early history and the beginnings of the cult are far from clear. Excavations undertaken in four distinct periods between 1890 and $1925^{4}$ brought to light Early Iron Age material, mainly pottery, abundant enough to demonstrate the originality of the local style. Recent works at the Amyklaion, under the joined direction of the Benaki Museum and the 5th Ephorate of Prehistoric and Classical Antiquities, were successful in revealing for the first time architectural remains associated with the layout and organization of the Geometric sanctuary. The significant quantity of the Early Iron Age pottery that came to light in relation to the number of votive offerings provides new evidence for the development of the Laconian Protogeometric and Geometric style and throws much light on the progressive organization of the sanctuary area and the consolidation of the festival, presumably established already by the second half of the 8th century BC.

During the first excavations on the hill, Tsountas ${ }^{5}$ investigated close to the west end the remains of ancient constructions that he considered as the earliest remains and were later identified by Furtwängler and Fiechter ${ }^{6}$ as the altar of the sanctuary. Pottery, terracotta and metal items were recovered from a mixture of ash, charcoal, animal bones, sheep horns and bovine teeth-the debris of many centuries of sacrificial activities. The material spread in the wider area in and around the constructions, as well as to the north and mainly to the south and east, was much disturbed and not chronologically homogeneous. The largest corpus of the Early Iron Age material seems to have been deposited along the peribolos wall of the sanctuary possibly representing secondary deposits from the top of the hill. The area had been partly investigated already in the 1920s; it is however during the most recent works that an earlier enclosure wall was revealed $6.5 \mathrm{~m}$ to the north of the classical monumental peribolos of the sanctuary. The wall is $30 \mathrm{~m}$ in length and ca. $2.10 \mathrm{~m}$ in width and can be dated on the basis of the pottery that was found at its foundation level to the late 8th century BC. This is the first documented attempt of a better organisation of the space, possibly an effort to create more space on the top of the hill by retaining the large hill bank and at the same time marking the space of the sanctuary. ${ }^{7}$

\section{THE PROTOGEOMETRIC POTTERY}

Pottery forms the main corpus of evidence for the EIA activities on the hill. The transition to the Early Iron Age and the dating of the PG style in Laconia ${ }^{9}$ have been much debated in scholarly research, mainly in the absence of stratified deposits ${ }^{10}$ and any architectural remains. Arguments have been focused on the numerous pottery assemblages from the excavations of the late 19th and early 20th cen- 


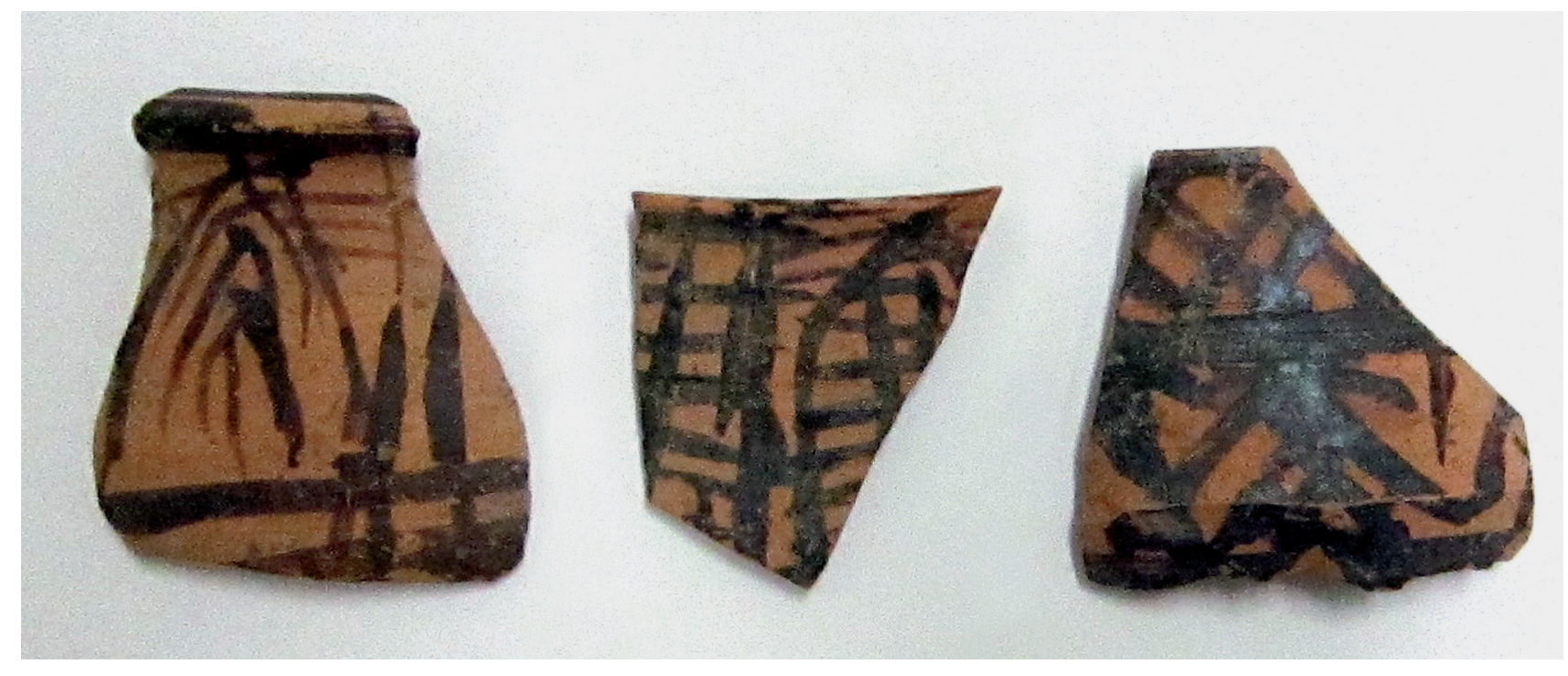

turies at the Amyklaion, mainly because of the rarity of contemporary material from the rest of Laconia. Early Laconian pottery displays an originality of shapes and decorative motives almost unparalleled to the prevailing Attic PG style. Nonetheless, the development of the PG style in Laconia and the much discussed chronological 'hiatus' between the Mycenaean and EIA material need to be reconsidered upon the new evidence.

The provenance of several Laconian shapes from the preceding Mycenaean repertory has been convincingly demonstrated by W. D. E. Coulson, ${ }^{11}$ who also emphasized the strong connections between the pottery productions of Laconia and Messenia during the same period. Although the beginnings of this production were traditionally placed with a delay in relation to the Attic PG series in the middle of the 10th century BC, there seems to exist enough evidence to uphold a continuity of the PG series from the late 11th century BC. If there was a gap on the Amyklaian hill, this should certainly have been narrow and the frequentation of the area would have very soon resumed.

The latest examples in the series of the LH IIIC wheelmade bulls are decorated with superimposed triangles and semi-circles executed free hand, cross-hatching and vertical zigzags in between vertical straps. ${ }^{12}$ All motifs belong to a local Sub-Mycenaean style, also evident on contemporary pottery of a Sub-Mycenaean phase that enters the 11th century BC. ${ }^{13}$ Few pottery sherds found at the Amyklaion seem to belong to a transitional phase and are decorated

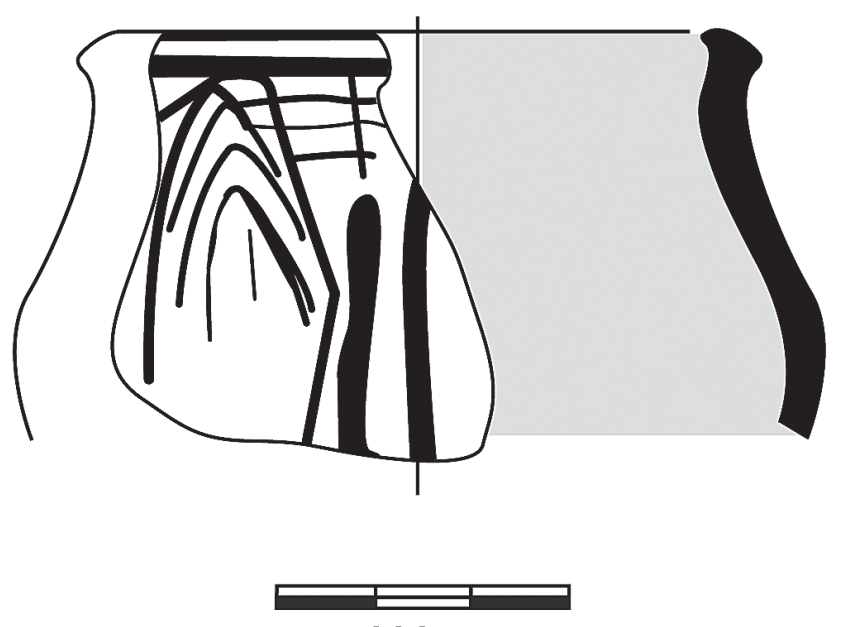

AM 32

Fig. 1a. Sherds of PG skyphoi.

Fig. 1b. Drawing of the first left sherd in fig. 1a.

with Sub-Mycenean motifs, although in a different matter, almost exclusively from small open vessels. Although the earliest pieces are few in number, they mark the beginning of a remarkable consistency in the series of the PG pottery found at Amykles. The earliest examples are characterised by the rough and sketchy execution of the decoration (figs $1 a-b)$, as well as the horizontal grooving of the surface of the vessels that is characteristic of the local PG style. Few pieces of Sub-Mycenaean and EPG style display strong similarities to the Attic and Argive series, and a provenance 

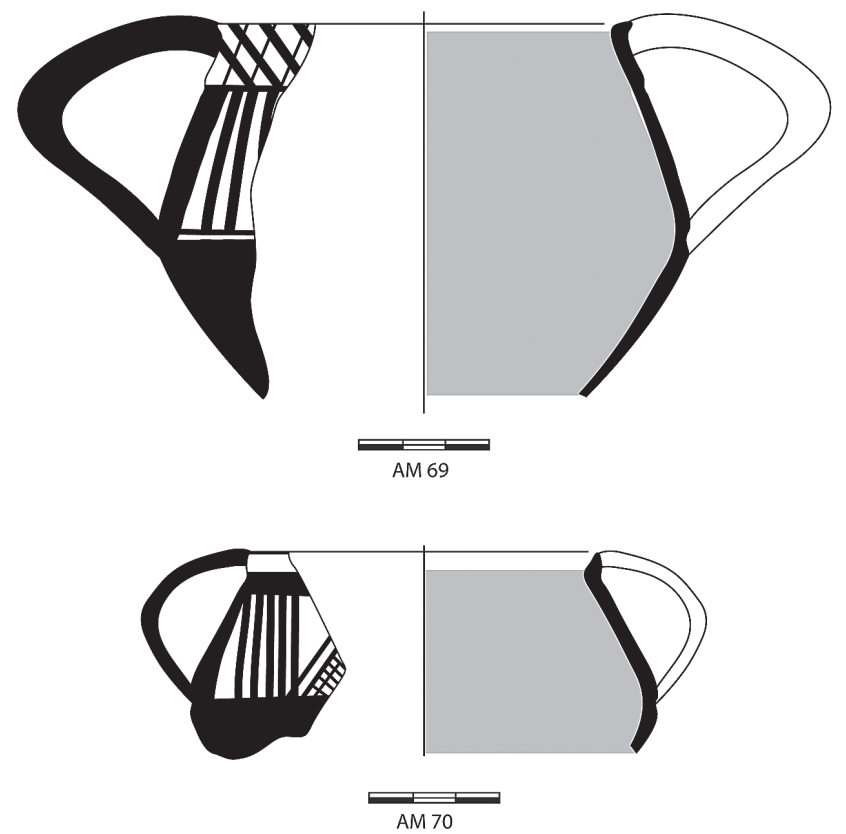

Fig. 2. Drawing of PG fragmentary kantharoi from the Amyklaion.

from those regions seems quite possible. A continuity in the ritual activities during the same period is suggested by the presence of a small number of ribbed stems of early PG kylikes; the shape seems to survive during this period in Western Greece (Ithaka, Tiryns, Olympia, Amyklai) and Crete (Faistos) ${ }^{14}$ demonstrating a continuity in the ritual symbolism and use of this certain type of pottery.

Following these early developments, activity on the hill amplifies from the 10th century BC onwards and the first important phase spanned the LPG period and the early years of the Geometric. In this framework, we are more inclined to use the terms of Protogeometric and Sub-Protogeometric for the continuation of the PG style in the first half of the 8th century than the term Dark Age pottery suggested in the ' 80 s by Coulson. The large corpus of the Protogeometric pottery is easily distinguishable by the hard fired fabric that varies in colour from light brown to red and the good quality of the black paint that gives a metallic shinny impression, possibly due to the high firing conditions. ${ }^{15}$ For the black monochrome wares this metallic impression of the black paint is displayed on the exterior and the interior surface. It should be noted however that not all pieces give this metallic impression of the black paint, while the colour of the clay that is usually for these pieces lighter and buff in colour possibly indicates a different pottery production, although not necessarily a non-Spartan one. PG pottery lacks any trace of slip, and the surface of the vessels is smooth and very well polished.

Although a statistical analysis of the pottery is in progress but not yet completed, the fragments of small open vessels form by far the largest part of the pottery assemblages. Skyphoi and cups are the commonest forms of small open vessels. Two types were distinguished by Coldstream; the flaring skyphos, with rather shallow profile and lip that overhangs the body, and the bellied skyphos, a type better defined later by Coulson, who also added the deep and the carinated type. ${ }^{16}$ The deep skyphos is the least represented in the Amyklaion assemblages and the type of the decoration displayed on the skyphos from the Heroon ${ }^{17}$ can only be seen on few skyphoi of MG date and also to few sherds of early lakainas ${ }^{18}$ possibly of the same date. The carinated skyphos is one of the most characteristic types of Laconian PG, with a narrow rim and a diameter reaching usually between 8 and $12 \mathrm{~cm}$. A high conical foot has been restored for this type of skyphos that would match the numerous conical feet found at Amyklai. ${ }^{19}$ It seems however that the same carinated profile is not restricted only to skyphoi, but is equally shared by kantharoi.

A substantial number of kantharoi has been identified in the material from the most recent excavations that contradicts older remarks on the absence of the type from the Laconian PG series, while its development shows many similarities with the specimens found in Aitolia, Elis, Achaia and the Ionian islands. The surface of the lower body is always covered with black paint and decoration is restricted on the lip and the handle zone (fig. 2). Horizontal grooving seems a standard element for this class of kantharoi, and a conical foot may also be restored, similar to that of the skyphoi. An intact kantharos, rather late-in-date, was found in gr. 7 at Amykles. ${ }^{20}$

Large open vessels are the least represented among the open shapes in the assemblages from the Amyklaion. Two profile shapes predominate; the first follows the shape of the skyphos, although in larger dimensions and a diameter at the lip that reaches $42 \mathrm{~cm}$ for the largest example. ${ }^{21}$ The second type has a deeper profile shape and a fragment recovered from the rim of a PG krater preserves part of the attached vertical strap handle. The largest examples dated in the LPG reach a lip diameter of $40 \mathrm{~cm}$.

Closed shapes are less frequent. The much fragmentary 
material consists mainly of small slow pouring vessels such as lekythoi, trefoil oinochoe and hydriae. ${ }^{22}$ A substantial number of fragments from the shoulder and body of small hydriae and possibly oinochoe follow a biconical profile of the body. ${ }^{23}$ The complete oinochoe from Heroon at Sparta ${ }^{24}$ finds no close parallels in the material from the Amyklaion. The rarity of large closed vessels in the PG ceramic assemblages may be compared with contemporary assemblages from other Greek mainland sanctuaries, notably the Pelopion material at Olympia, Isthmia in Corinthia and Kalapodi in Central Greece. ${ }^{25}$

The only evidence of a large closed vessel that does not relate to any feasting activities consists of a few joining sherds of an unidentified shape that looks early in date. The sides are only slightly convex, while the shape and decoration seem better matched to the shape of a clay box or the so-called stamnos pyxis of the PG period. ${ }^{26}$ Although the shape has not been previously attested in the Laconian repertory, a small number of sherds dated to the LPG and the EG period can be now identified in the Amyklaian assemblages. The distribution of the type in the Greek mainland during the PG period is limited, while few examples are known from Argos and Tiryns dated to the LPG. ${ }^{27}$ A single extremely fragmentary example is reported from Asine, associated with phase 1 or 4 of the Karmaniola settlement. ${ }^{28}$ The later, along with the pyxis from Argos, share common decorative elements, namely the use of cross-hatching. The Amyklaian specimen seems to follow the Argive examples, while the EG pyxides found at Amyklai show similar inspiration.

Contacts with the Argolid may be demonstrated on pottery evidence, already from an early period. Laconian pottery has been reported at Asine already from phase $1 .^{29}$ Among the earliest Laconian sherds from the $\operatorname{area}^{30}$ is a body sherd of a skyphos is decorated with a cross-hatched butterfly motif and interlocking cross-hatched standing triangle. ${ }^{31}$ This motif is quite popular in both Amykles and Asine and despite the limitations posed by the disturbed PG layers at Asine ${ }^{32}$ an early date, possibly in the second quarter of the 10th century BC should be suggested for these pieces. The motif is frequently used for the decoration of small open and closed vessels in the LPG. ${ }^{33}$ The earliest imported sherds from the Argolis, presumably from Asine, should be dated at around the same period: MPG late/LPG. ${ }^{34}$ Laconian pottery is attested in almost all the phases of the Karmaniola settlement at Asine. ${ }^{35}$
PG sherds of the 'Amyklaian style' have been found at Tegea, inside the deposit revealed under the pronaos of the later 4th century $\mathrm{BC}$ temple and below the metal workshop of the late 8th century BC, also located in the same area. ${ }^{36}$ Laconian PG sherds were identified in most of the stratified layers of the above deposit of mixed Mycenaean, EG and MG sherds. The situation described is very similar to that of the deposits from the Amyklaion and in this respect does not provide any solid evidence as to the chronological succession of the pottery. The deposit in the area of the later sanctuary has been associated with a presumably open-air shrine at the site. The presence of Laconian pottery in this early cult place demonstrates the connections with the Eurotas plain and namely with Amykles, while M. Voyatzis has argued for an extension of the 'Laconian territory' as far to the north as Tegea.

Within Sparta, only a few sherds of PG style have so far been found at the most important cult places - the Acropolis, the Sanctuary of Athena Chalkioikos, the Heroon, the Sanctuary of Artemis Orthia ${ }^{37}$ and further to the south of Sparta on the West of the Eurotas plain in the area of Anthochori, where the Sanctuary of Zeus Messapeus has been identified. ${ }^{38}$ However those specimens, cannot be compared with the large quantities revealed at the Amyklaion, and it may be suggested that the area of the Amyklaion was functioning as the most important cult center of the Spartan plain during this time.

\section{THE GEOMETRIC POTTERY}

While Sub-PG style seems to continue at Amyklai as far as the middle of the 8 th century $\mathrm{BC},{ }^{39}$ Argive and in a lesser degree Corinthian influences penetrate the strong local pottery production. Droop and consequently Coldstream ${ }^{40}$ detected an intervening stage between the SubPG and the LG Laconian style in the use of circle motifs; those seem to enter the local repertoire possibly in the LPG. They become a popular decorative motif for both open and closed vessels of Sub-PG style and continue in the Late Geometric period. The transition to the LG style is better illustrated in a number of small open vessels, mainly skyphoi, that draw their shape from the MG Attic, Argive and Corinthian repertoire, while their decoration from the strong Laconian tradition. The shape seems foreign to the local repertory, with a low vertical or slightly 


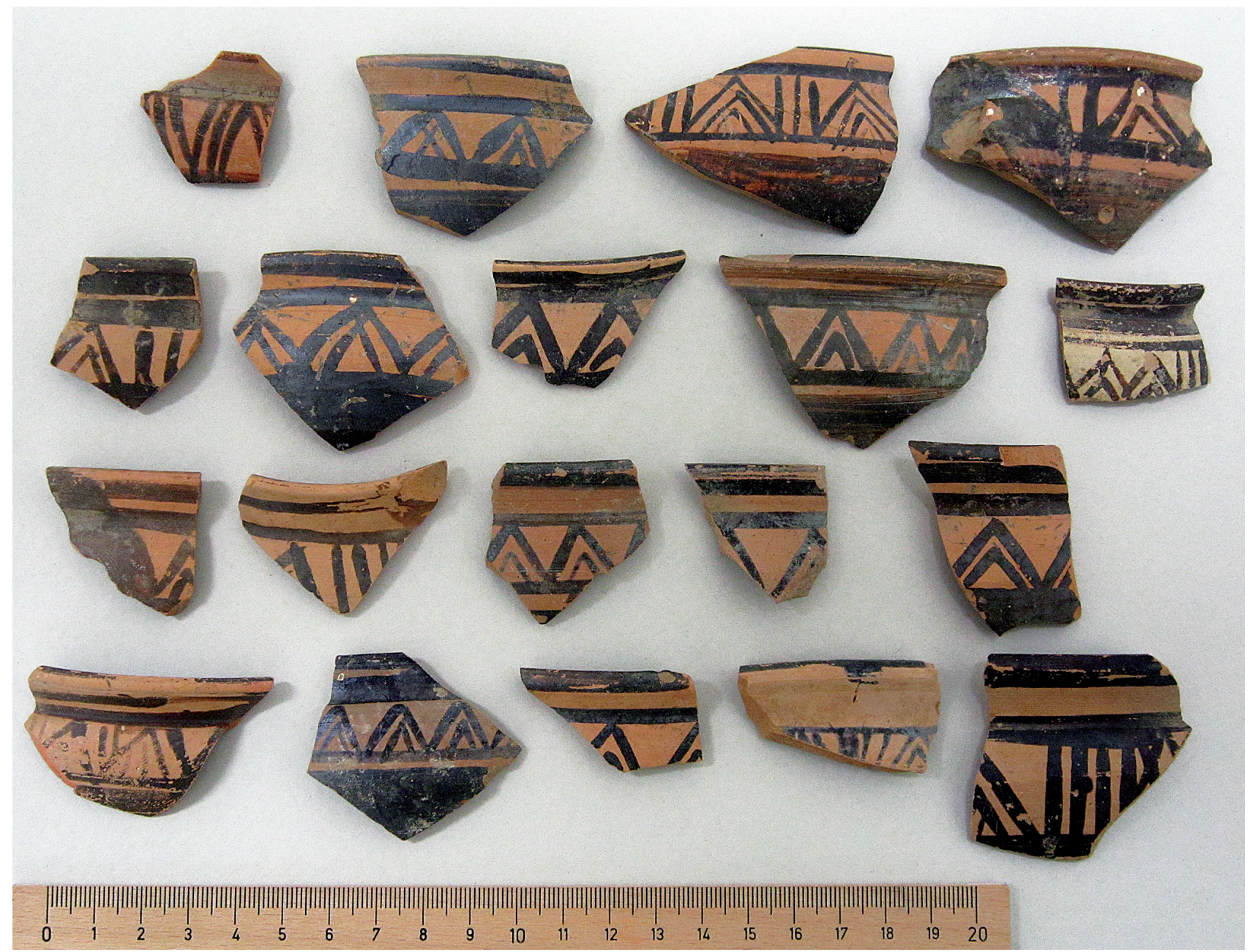

Fig. 3. Fragments of MG and early LG skyphoi from the Amyklaion.

off-set lip, shallow body with accentuated shoulders and a low ring foot. Most of those skyphoi are decorated with superimposed triangles placed in rows in the zone between the handles, while the rest of the surface is covered in paint (fig. 3). ${ }^{41}$ The choice of triangles as a decorative motif lies entirely in the PG Laconian pottery tradition. The latest in the series are covered with a nice light coloured slip, indicative of the pottery production of the LG period (fig. 3, second row, right end). Alternatively to the triangles, horizontal parallel lines or single zigzags, horizontal lozenge chains and vertical bars are also shown, probably deriving from contemporary Attic and Argive models. The latter examples are all of small size; the diameter of the lip ranges between 5 and $10 \mathrm{~cm}$. Meanders with diagonal hatching and the steep single zigzag seem to have been introduced under MG Attic influence, however their popularity during the LG period seem closer to the Argive LG.

A new form, the globular pyxis appears during this period, possibly under a strong Argive influence and fades away soon afterwards. ${ }^{42}$ Only a few fragments of pyxides were found in the Amyklaion assemblages, all sharing the tiny everted rim, while the larger specimens preserve the suspension lugs closely placed to the rim. The decoration of the surface for this presumably earlier example is limited to triangles and rectangles filled with crosshatching, which although consistent with the local tradition, is close to the Argive specimens as well. Those from Amykles are very fragmentary and there is no evidence as to the profile of the lower body and base. A low ring base may presumably be restored, following the example 


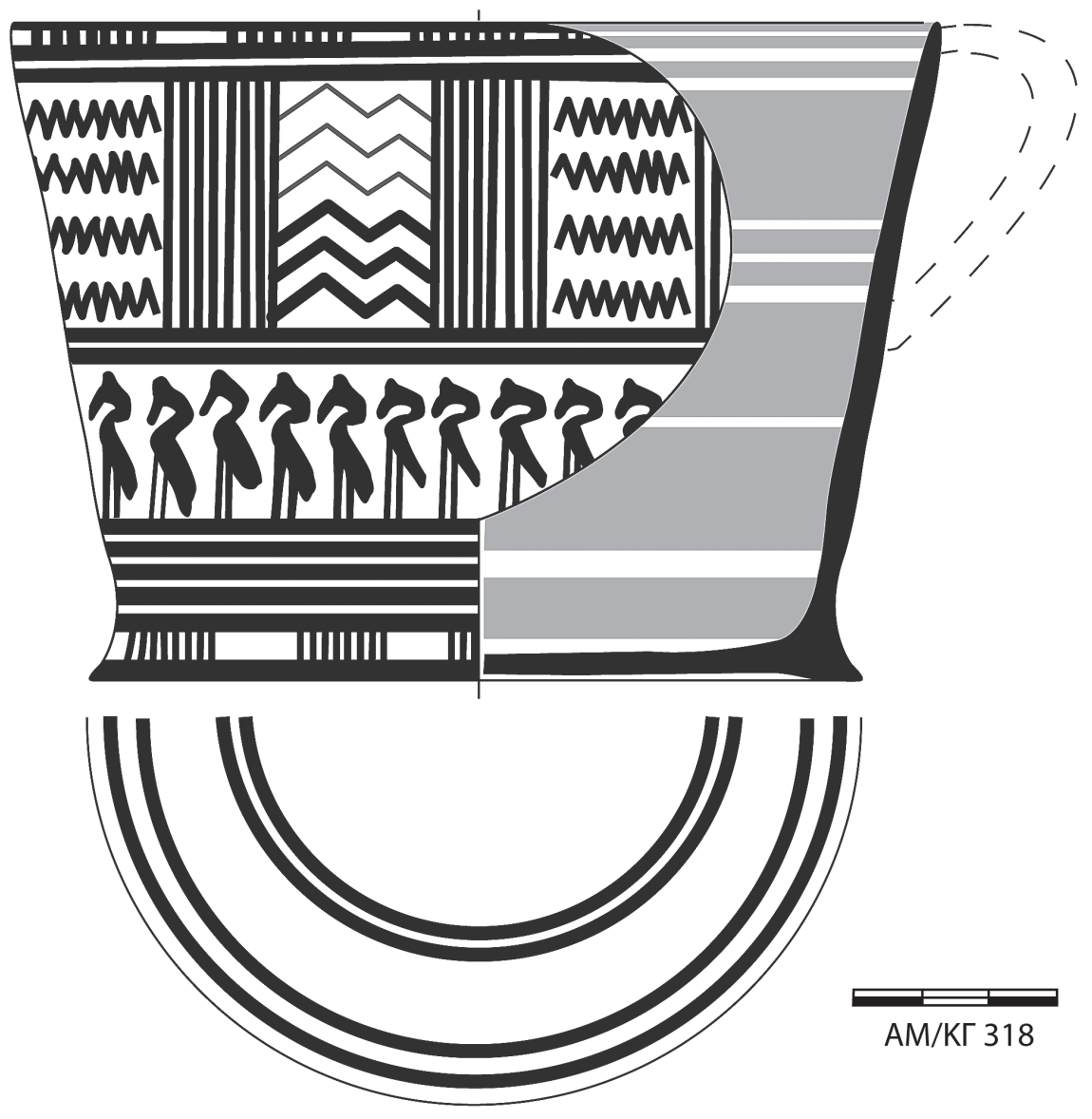

Fig. 4. Drawing of an LG deep cup from the Amyklaion.

from Kalapodi ${ }^{43}$ which also shares with the Amyklaian specimens common decorative motifs.

The middle of the 8th century and the beginning of the LG period at Amykles is marked by major changes in the material culture that is also reflected in the ritual practices. An influx of imported pottery should be associated with a possible amplification of the cult and the attraction of worshippers on the hill, while votive offerings such as clay and bronze tripods, arms and pieces of armour ${ }^{44}$ are consistent with the deployment of games possibly within the festival.

New pottery shapes and a variety of decorative motifs mark the beginning of the LG and persist until the end of the period. A thick light coloured slip is now applied on the surface of most vessels. Although the largest corpus of the material seems to belong to a local production, a substantial number of different fabrics seem to point to imports and possibly different workshops active in the wider area. Skyphoi with tall slightly off-set lip and one handled deep cups are among the most popular shapes. Skyphoi are distinguished by their tall lip which forms a gentle convex curve and full shoulders, where the horizontal handles are attached. ${ }^{45} \mathrm{~A}$ characteristic horizontal grooving at the outer rim may be seen in almost all the specimens, while the decoration of the surface is limited to horizontal wavy lines and lozenge chains placed in the handle zone. The lower part of the body cannot be safely restored, although it seems that the walls turn inwards, more or less abruptly just below the handles. ${ }^{46}$ The diameter of the lip is rather fixed around $9-10 \mathrm{~cm}$. The origin of this type of skyphos may be traced in the carinated skyphoi of PG and Sub-PG style ${ }^{47}$ and seems to develop entirely in the local style, independently from parallel forms in Attica and Boeotia during the LG period. ${ }^{48}$ The invention of the Laconian lakaina has been traced in the LG period ${ }^{49}$ and it is possible that the shape developed from the form of 
the high-rimmed skyphos of the LG period. The shape is inextricably related to the Laconian pottery repertoire, developed specifically in the local workshops as one of the most typical shapes of the Archaic period. ${ }^{50}$ The earliest examples of the shape do not seem to predate the late 8 th century $\mathrm{BC} ;{ }^{51}$ the lip is tall and slightly convex, the body almost biconical with two horizontal handles attached at the wider diameter and a flat base. The decoration of the surface is very close to that of the high-rimmed skyphoi of the LG, with horizontal straps on the lip and short vertical bars on the outer rim. A few fragments of the lower body and base found at the Amyklaion seem to belong to small and miniature lakainai.

The profile shape of the deep cup is best provided by a quite fragmentary example (fig. 4); its walls are almost vertical, slightly converging towards the low disc base, the diameter of the lip does not exceed $14 \mathrm{~cm}$. The vertical loop handle is attached to the lip and the middle of the body. The multiple zigzags placed in panels on the upper part of the body and the zone of stylised soldier birds on the lower body offer a date late in the last quarter of the 8th century BC. Close in date should be the two almost complete examples from the excavations of Tsountas in the area of the sanctuary, ${ }^{52}$ which have been seen as either pyxides or cups. Both vases have the characteristic grooving on the outer rim and slightly convex walls which better match with the profile shape of deep cups. ${ }^{53}$ The decoration develops in successive zones, while nude males seem to perform a circular dance on the large upper zone of the deep cup, today in the National Museum at Athens. The type persists into the early Archaic period, usually with an off-set lip, flat base and a smaller loop handle. ${ }^{54}$

One-handled monochrome cups continue in the 8th century BC, and cups decorated with vertical and oblique lines either until the middle of the body, leaving the rest painted black or reaching all the way until the flat base. Among the less common open vessels are few skyphoi with short offset lips and shallow bodies. A few kantharoi may be distinguished from the fragmentary high strap handles. An addition of the late 8th century $\mathrm{BC}$ is the broad shallow dish, usually with two horizontal handles attached at the rim and a low ring base. The large size of certain specimens and the fine decoration of their surface seem in favour of a ritual use or a votive character of these plates. Thick light coloured slip is applied on the surface of most examples. Shape and decoration are very close to those from the sanc- tuary of Artemis Orthia ${ }^{55}$ and Argos. ${ }^{56}$

LG kraters are quite numerous during this period from Amykles, however extremely fragmentary and thus a reconstruction of the entire profile remains tentative. The decoration of the surface displays the strong Argive influence, while the shape should be of local inspiration and does not match the shape of Argive or Corinthian kraters. The typical horizontal grooving on the outer rim may be seen in most of the examples, and the walls are almost vertical. The diameter of the rim rarely exceeds $20 \mathrm{~cm}$. The profile shape seems to match with a type already distinguished by Droop from the sanctuary of Artemis Orthia ${ }^{57}$ and a further development is demonstrated by a later specimen, very close to a krater from Menelaion. ${ }^{58} \mathrm{Few}$ kraters of this type, although burnt and thus badly preserved, seem to have been coated with a thick slip, typical of the local production; decoration varies from panelled geometric motifs to figured decoration. The deep body with a gentle convex profile persists in the 7 th century BC and it is only the lip that develops in a more articulated form. The diameter of the rim reaches ca. $36 \mathrm{~cm}$ which indicates a vessel significantly larger than its Geometric predecessors. Imported Argive kraters and Laconian imitations are also of medium size and the diameter of the lip reaches ca. $20 \mathrm{~cm}$.

A clear difference in the LG ceramic repertoire with that of the earlier period is the presence of closed shapes, namely amphorae. Belly-handled amphorae with tall necks and groups of concentric circles for the decoration of the surface $^{59}$ that are quite common in the Spartan sanctuaries, are also represented in the Amyklaian material, although in a much fragmentary state.

One more addition in the LG local repertoire is represented by the globular aryballos at the end of the 8th century BC, which developed into the typical clay offering at the sanctuary from this period onwards. The earliest examples are imported Corinthian. A large number of painted globular aryballoi have so far been found, very few intact, while an enormous amount of handmade miniature aryballoi were dedicated to the sanctuary presumably from the late 8th century onwards. The shape seems to replace the small-sized lekythoi and hydriae of the PG and EG period, presumably related to the ritual activities.

The appearance of a figured style in the second half of the 8th century BC reflects the early elaboration of the fine pottery decoration. Whether this class of fine pottery 


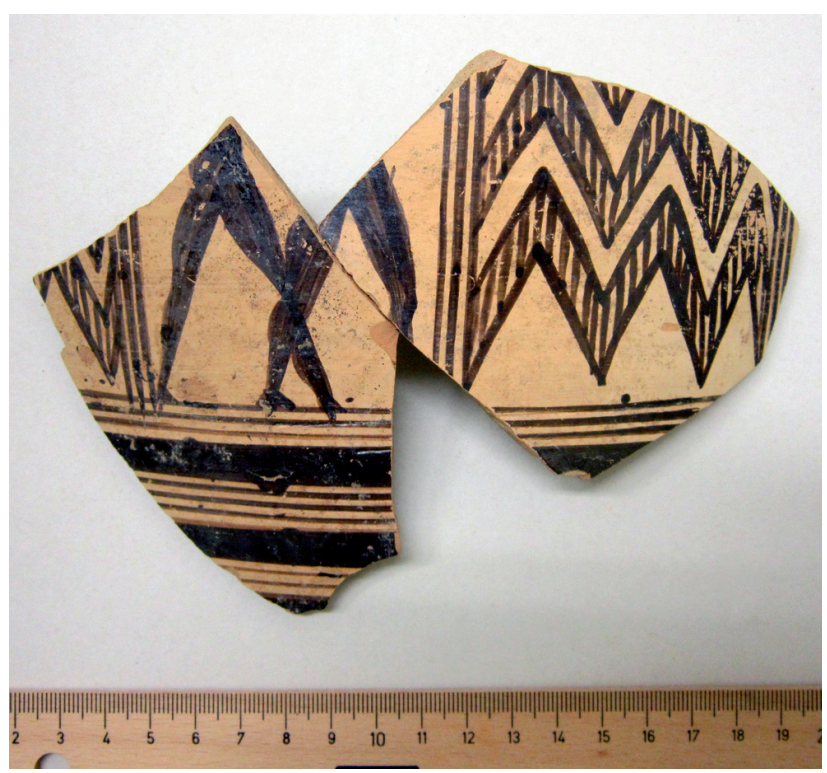

Fig. 5. Fragmentary LG krater with figured decoration.

was made for specific cultic use or not, figured scenes are usually shown on the surface of skyphoi and kraters and only rarely on amphorae. A number of fragmentary pieces from the most recent excavations may be added to the figured repertory from Amykles, demonstrating a strong local taste. Male dancers are the most frequent and typical representations at Amykles. ${ }^{60}$ A pair of dancers or possibly athletes are shown on the surface of a small krater moving to the right (fig. 5); the fine drawing, the unusual posture of the two figures and their placement in a panel find no close parallels in the material from Sparta, revealing presumably the inspiration of an individual artist. ${ }^{61}$ Depictions of female dancers and horses display strong Argive influences, while some fragmentary kraters may have actually arrived from the Argolid. Other iconographical themes involve battle scenes and armed men, as well as rarer representations of lions and centaurs, ${ }^{62}$ so far unparalleled in the material from the other Spartan sanctuaries.

One large category of clay dedications to the Geometric shrine consists of a few loomweights and miniature vessels mostly handmade bowls and cups, frequently decorated with incised motifs (fig. 6). This is a common class of finds found in most of the Peloponnesian sanctuaries during the Geometric and Archaic period. ${ }^{63}$ Lastly, although clay figurines are rather rare in the Geometric material from the sanctuary, two terracotta heads of a helmeted warrior and a female figurine were found close to the altar during Tsountas' excavations. Few more fragments from the recent excavations may also come from clay figurines.

\section{PRELIMINARY CONCLUSIONS}

Ceramic assemblages reveal a continuity in the use of the area from the late 11th/early 10th century BC onwards. Pottery is consistent with small gatherings that would initially have taken place on the hill. The use of table wares, mainly small drinking vessels and the presence of larger kraters indicate that drinking and presumably dining would have formed the nucleus of those collective activities during the EIA. Larger quantities of pottery should equate to a larger number of people that would have gathered on the hill progressively until the late 8 th century BC. Coarse and culinary wares are extremely fragmentary and difficult to date without any stratigraphical evidence; it seems however that few should be dated in this period, while the presence of some miniature cooking wares provide some additional evidence.

The 8th century BC demonstrates an increased range of votives suggesting an apparent escalation in the activities. From around the middle of the 8th century BC alternations and variations of the material record may be taken as indicatives of transformations of the ritual practices. Although the nature and basic function of the greatest amount of pottery did not change, the increased elaboration of the drinking and dinning sets, as well as the imported wares, suggest a differential investment by the participants in the basic feasting equipment.

Large amphorae that appear for the first time in the LG period may possibly associated with a need of transportation and storage of the goods, presumably indicating a longer stay of the worshipers on the hill, as it is known in later times during the three day celebration of Hyakinthia. Among the dedicated clay objects, the aryballos constitutes since the late 8th century BC the commonest offering at the sanctuary; either wheel-made and painted or miniature handmade ones. Figured pottery displays the deployment of dances and athletic contests probably during a festival, and the dedication of tripods strengthens this suggestion. During the same period the sanctuary area is delimited by a large enclosure wall, while more space seems to have been gained on the hill-top, possibly to accommodate the in- 


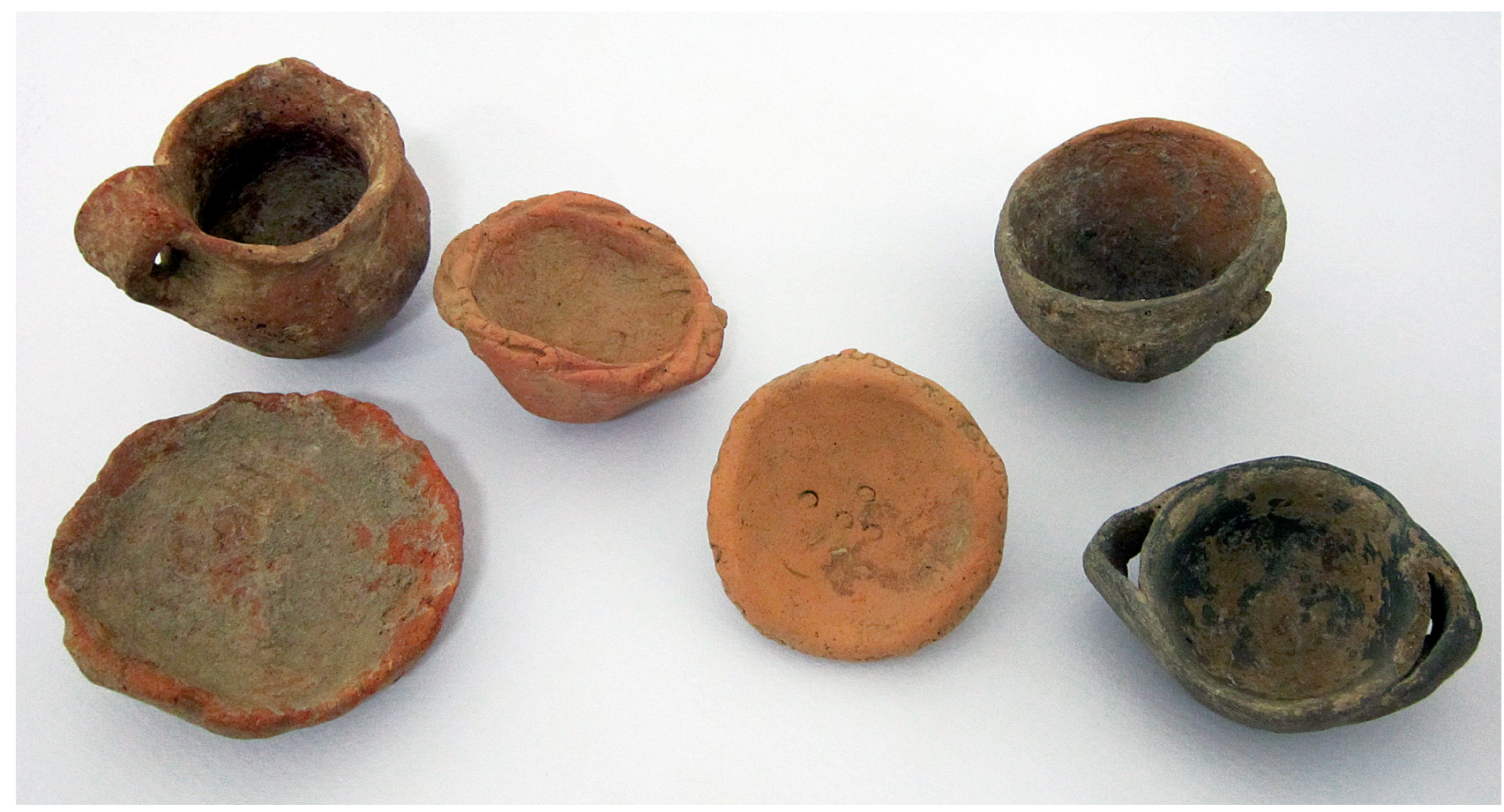

Fig. 6. Handmade miniature offerings from the Amyklaion.

creasing crowd and the various stages of the rituals. Lavish dedications of material wealth and status that appear at the same time are consistent with the performance of games and dance or athletic contests within a festival. Moreover, if we accept a certain reality of the tradition that associates the Hyakinthia festival with the events that led to the foundation of Taras at the late 8 th century BC, ${ }^{64}$ then the festival should have already had a more definite form by that time.

On the above preliminary considerations it becomes evident that the early beginnings and progressive consolidation of collective activities performed at the Amyklaion by the small communities of the Spartan plain led to one of the most important religious festivals of the Spartans. In this perspective, it may be possible to associate the im- portance of the Amyklaion sanctuary with the seniority of the shrine and the continuity of the collective and ritual activities in this same area during the centuries. Whether activities initiated around a cult of the dead buried on the hill, as it has been already suggested, ${ }^{65}$ is difficult to demonstrate on archaeological evidence. Nonetheless, the quantity, quality and diversity of the EIA material from the Amyklaion, unparalleled so far to the other Spartan sanctuaries, offers a prominent case of a Bronze Age background for the Early Iron Age cult in the same area.

Vicky Vlachou

hekataios@yahoo.gr

vasiliki.vlachou@ulb.ac.be 


\section{OTES}

* My warmest thanks to Prof. Angelos Delivorrias and Dr Stavros Vlizos for inviting me to study the Early Iron Age material from the Amyklaion and for their continuous and active support. I am thankful to Dimitris Sourlas for his help during the various stages of this study. As this is an ongoing excavation and material is prepared for final publication, suggestions in this paper should be taken only as preliminary that may be modified in view of the rest of the material uncovered in the sanctuary. All photos and drawings are by the author.

1. The site was first identified by Leake 1830, 144 and confirmed by the discovery of stamped tiles with the name of Apollo Amyklaios and by epigraphical evidence. Tsountas 1892, 3; Fiechter 1918, 223 nos 11, 12; Buschor - von Massow 1927, 61-64 nos 1-16; Vlizos 2009, 11-13. For a detailed treatment of the literary and epigraphical evidence, $c f$. Pettersson 1992; Moreno-Conde 2008.

2. In the modern village of Amykles, a burial group with 12 PG graves was investigated and a substantial quantity of Protogeometric and Geometric pottery reinforces the identification of the EIA settlement on the same area. E. Zavvou, AD 51 (1996), Chronika B1, (D. Konidaris plot) 129-31, pl. 45a-b; ead., AD 53 (1998), Chronika B1, 172-73.

3. For a short treatment of the bibliography on the throne of Apollo, $c f$. Vlizos 2009, 12-13; Delivorrias 2009.

4. Tsountas 1982; Fiechter 1918; Skias 1907, 104-07; Buschor - von Massow 1927; for a short history of the excavations in the sanctuary area, $c f$. Demakopoulou 1982, 2942; Calligas 1992, 31-33; Pettersson 1992, 92-99; MorenoConde 2008, 61-69.

5. Tsountas 1892, 1, 7-8, 11-12.

6. Fiechter 1918, 162-65; Calligas 1992, 33-35.

7. Vlizos 2009, 14.

8. Desborough 1952, 283-90; Demakopoulou 1982; 2009a; 2009b; Snodgrass 2000, 130-31, 395; Eder 1998, $97-$ 111; Pettersson 1992, 91-100; Cartledge 2002², 70-80.

9. The chronology of the pottery had to be established by means of stylistical analysis alone. Desborough 1952, 28390; Coulson 1985; 1988a; 1988b; 1991; Margreiter 1988; Eder 1998, 99-113; Cartledge 2002², 70-80.

10. Evidence for stratigraphy is far from safe, as pottery was found outside and below the terrace wall; Buschor - von Massow 1927, 24-33; Coulson 1985, 63-64.

11. A provenance from the preceding Mycenaean repertory has been demonstrated for several Laconian shapes, such as the carinated skyphos, the flaring skyphos, the krater and certain types of cups, cf. Coulson 1985, 38-39, 44-45, 57-58, $61-66$; 1986, 35-48, 55-56; 1988b; for the Laconian isolation as a reason for the late occurrence of the PG style in the region, $c f$. Desborough 1952, 284, 287-88; 1968, 243; Cartlegde 2002², 70-80; contra Pettersson 1992, 97-100.

12. Buschor - von Massow 1927, 38, fig. 6.14-15; Dema- kopoulou 1982, 57-58, pls 28.70, 29.10a-b, 30.72, 36.84; Demakopoulou 2009b, 100-01, figs 10.10a-b, 10.11; Guggisberg 1996, 55-57, nos 159, 164, 169-71, 173-76, pls 11-12. For similar types from Cos and Kalymnos, $c f$. Skerlou 2004.

13. Demakopoulou 1982, pl. 62:140; Demakopoulou 2009b, 119-121; AD 53 (1998), Chronika, 174-76, pl. 81b, 232 pl. 97a (8052); AD 55 (2000), Chronika, 272, figs 7 , 10; for similar motifs in the decoration of the latest figurines of the Psi type, $c f$. Alram-Stern - Deger-Jalkotzy 2006, 113-14, no. 44, pl. 26.44; the shape of the Amyklaian skyphoi is close to some contemporary examples from Tiryns, $c f$. Stockhammer 2009, 357 fig. 4.2-4.

14. Eder 1998, 97-107, 127-30, 136-38; 2001, 206-208; Morgan 2006, 244-45; Demakopoulou 2009a, 121.

15. For chemical analysis of few Laconian pieces from Asine, cf. Wells 1983, 64, 85.

16. Coldstream 1968, 212-14; Coulson 1985, 34-49.

17. Coldstream 1968, pl. 46c; Coulson 1985, 35 fig. 1 (no. 13).

18. For an early type of lakaina, Coulson 1985, 36 fig. 2 (no. 53). A larger number of fragments of this type have been identified in the material from the recent excavation at the site.

19. Coulson's type C1 (1985, 36 fig. 2, no. 39-41) is only rarely represented in the material from Amykles. For the origin of the shape in the LBA stemmed bowls, $c f$. Coulson 1983b, 66-67.

20. E. Zavvou, $A D 51$ (1996), Chronika B1, 130 pl. 45a; Kyrieleis suggests a date for the kantharos in late 10th/9th c. BC, cf. Kyrieleis 2006, 156-57 no. 69.

21. Coulson 1985, 54-55, fig. 9.

22. Coulson 1985, 62; for a complete profile of a small hydria cf. Buschor - von Massow 1927, 47 fig. 27; Margreiter 1988, pl. 1:5.

23. For similar profile although earlier in date, $c f$. Kyrieleis 2006, 187, pl. 71.337.

24. Coldstream 1968, pl. 46b.

25. Olympia: Eder 2009, 205; Isthmia: Morgan 1999, 26671; Kalapodi: Nitsche 1987, 35-49; Felsch 1980, 47-54.

26. Desborough 1952, 112-113, pl. 13; Bohen 1988, 13-18, pl. 1:3, 4.44; Lemos 2002, figs 2.1, 3.2, 4.3, 10.6.

27. Lemos 2002, 79; Argos: G. Roux, BCH 81 (1957), $653-$ 54, fig. 30; Tiryns: P. Aupert, BCH 99 (1975), 613-15, fig. 56.

28. Wells 1983, 105-06, 256 fig. 194.761.

29. Wells 1983, 19, 64, 83; Langdon 1985; Coldstream 1985.

30. Wells 1983, fig. 147.345-346.

31. Lemos 2002, fig. 28.1; Wells 1983, fig. 224.285 (PG grave 25).

32. Wells 1983, 19. 
33. A fragment with similar decoration from phase 3 at Asine, cf. Wells 1983, 247 fig. 188.692.

34. The fragmentary skyphos from Heroon seems of Argive inspiration and demonstrates early contacts between the two areas. Wells 1983, 122; Desborough 1952, 289.

35. Wells 1983, 83 fig. 61, 230 fig. 173.526.

36. Voyatzis 1990, 269-73; 1995; 2004, 188-90, fig. 2; 2005; Østby et al. 1994, 134.

37. Cartledge 1992; Eder 1998, 107-09; Kõiv 2003, 63-66.

38. Zavvou 2009, 29-31, fig. 4.7.

39. A similar classification has also been made for the pottery assemblages of Lefkandi (Euboea), where also a strong local tradition persists in the earlier stages of the Geometric period. For EG and MG material along with that of the SubPG period, $c f$. Margreiter 1988, 27-40. For similarities in the development of the local style, $c f$. Cos; Morricone 19721973.

40. Droop 1929, 60-63; Coldstream 1968, 214-15 pls $46 \mathrm{e}-\mathrm{g}$. The fragment that appears in pl. $46 \mathrm{f}$ is said to be from Chalkioikos, however in the Sparta museum it is placed with the old material of the German excavations at the Amyklaion hill.

41. Buschor - von Massow 1927, pl. 3.19; Margreiter 1988, fig. 4.20, pl. 9. 99-104.

42. The type of the small globular pyxis has been seen as an Argive invention of the early EG period, with Attic affinities and possible prehistoric origins. Coldstream 1968, 114, 116, pls 22e-f, 23h, 25d; Desborough 1973, pl. 31c; Courbin 1966, pl. 77.

43. Nitsche 1987, 44-45 fig. 62.2.

44. Tsountas 1892, 12; Demakopoulou 1982, 73-78; Calligas 1992, 41-44. For clay tripods, cf. Margreiter 1988, pl. 29.343.

45. Lane 1933-34, fig. 2 a-b; Coldstream 1968, 215-16; Stibbe 1994, 21.

46. A similar type from the area of Sparta, $c f$. Zavvou, $A D$ 52 (1997), Chronika B1, pl. 71d.
47. Coulson 1985, 36 fig. 2 (Type C2, no. 53).

48. Descoeudres 1976, 42-44; AD 20 (1965), Chronika B1, pl. 87a; Ruckert 1976, pl. 28:6; Paspalas 2006-2007, 43 pl. 1; Vlachou 2010, 254-61; E. Zavvou, AD 52 (1997), Chronika B1, 162 pl. 71 d.

49. Coldstream 1968, 215-16; Stibbe 1994, 21-24.

50. Droop 1908, 31 no. 3; Lane 1933-34, 102-04; Coldstream 1968, 215-16; Stibbe 1989, 73-113; 1994, 19-24.

51. Lane 1933-34, 102-03, figs 2c-d, pl. 20e; Coldstream 1968, pl. 46m; Stibbe 1990, 75-76, 87-88, figs 39-47; Stibbe 1994, 23, 99-100 no. A1-A7.

52. Tsountas 1892, pl. 4.1-2; Coldstream 1968, 215-16.

53. Coldstream has already noted the absence of lids for those examples. Coldstream 1968, 216; one more fragmentary example, possibly also a deep cup, $c f$. Zavvou, AD 52 (1997), Chronika B1, pl. 71c.

54. For an intact example from Sparta, $c f$. Themos, $A D 51$ (1996), Chronika B1, 109 drawing 4.

55. Droop 1929, 59 fig. 33, 61 fig. 34.

56. Courbin 1966, pl. 67 C.2570, C. 4128.

57. Droop 1929, 57 fig. 31 b.

58. Stibbe 1994, 22-23, fig. A.

59. Spyropoulos, AD 36 (1981), Chronika B1, pl. 58; Zavvou - Themos 2009, 113 fig. 11.13.

60. Tsountas 1892, pl. 4.2; Buschor - von Massow 1927, pl. 4; Tölle - Kastenbein 1964, 48-50; Margreiter 1988, 52 55, pls 26, 40; Pettersson 1992, 52; Langdon 2008, $277-79$.

61. A close parallel for the posture of the two males is offered by a largely contemporary Attic clay lebes in the National Museum at Athens (NM 810). Pernice 1892, 203-28, pl. 10; Hampe 1960, 54 fig. 38; Coulié 2013, 90-91 fig. 63.

62. Buschor - von Massow 1927, pl. 5.

63. Casckey - Amandry 1952, 194, pl. 52:185; Ekroth 2003; Hammond 2005, 416-33.

64. Strabo VI. 3,2-3; Moreno-Conde 2008, 19, 23-24.

65. Pettersson 1992, 96-97. 


\section{BA I $\Lambda$ IKH B $\Lambda$ AXOY}

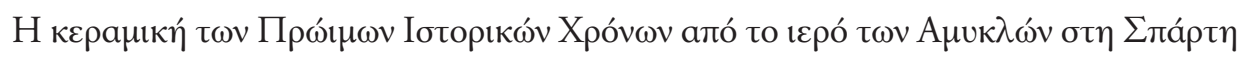

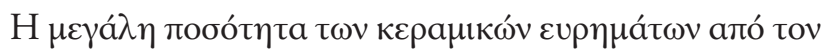

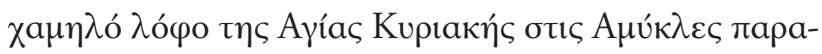

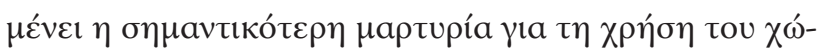

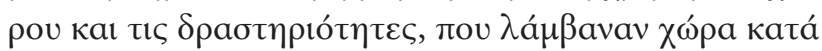

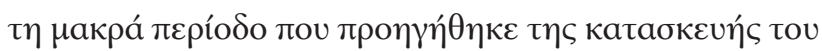

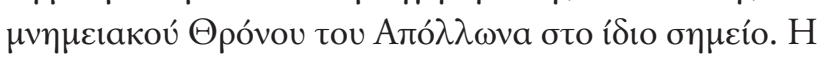

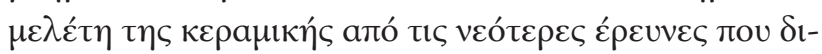

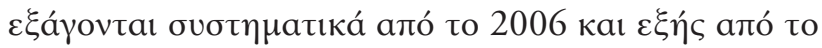

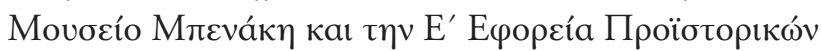

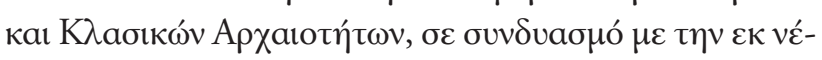

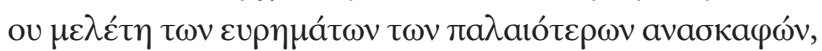

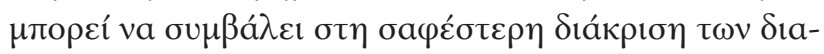

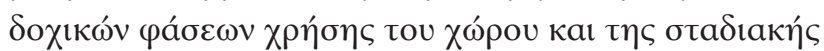

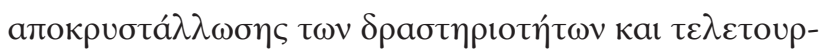

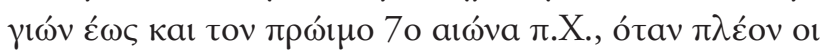

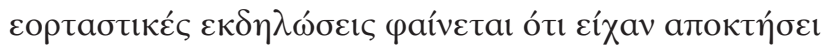

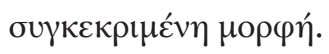

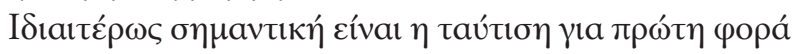

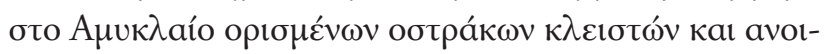

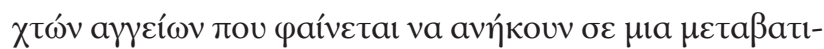

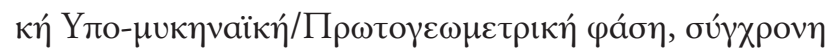

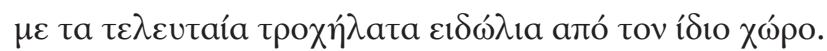

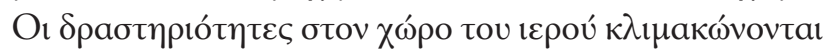

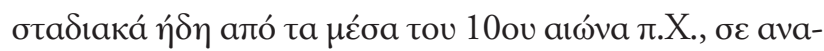

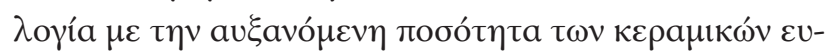

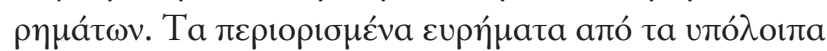

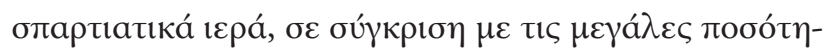

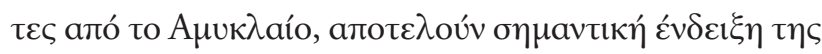

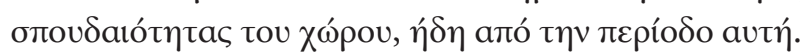

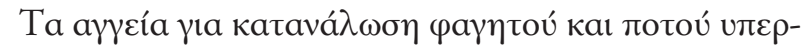

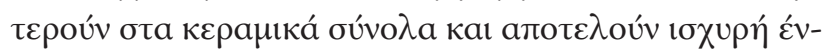

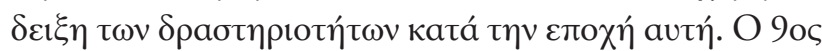

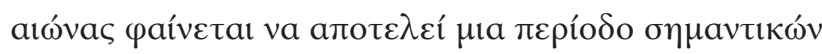

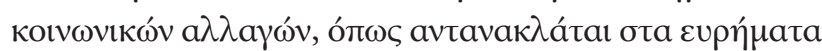

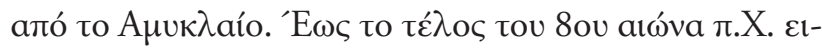

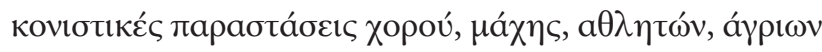

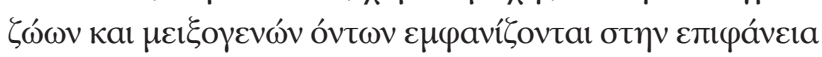

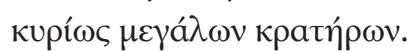

